\title{
EFEK GREEN MARKETING MIX TERHADAP MINAT BELI PRODUK RAMAH LINGKUNGAN
}

\author{
Krismi Budi Sienatra \\ Fakultas Manajemen dan Bisnis Universitas Ciputra \\ krismi.budi@ciputra.ac.id \\ Egar Sekar Evani \\ Fakultas Manajemen dan Bisnis Universitas Ciputra
}

Masuk : 13-12-2020, revisi : 08-01-2021 diterima untuk diterbitkan : 08-01-2021

\begin{abstract}
The spread of environmental issue requires business units to prioritize sustainability in the system or products. Gradually the community becomes more aware of life environmental damage and efforts to preserve the environment. Under the conditions, like this environmentalfriendly-products are shown by several product and service industries. The purpose of this research is to find out whether green product and green promotion have positive impact on purchase intention of Eco bouquet product. The variables that are used are Green Product (X1), Green Promotion (X2) and Purchase Intention (Y). The object of this research is a florist who provides flower bouquets and souvenirs. The populations of this research are potential buyers and all the followers in promotion media, totally 150 people. Sample number collection in this research were accidental sampling technique on potential buyers, that is, a technique that is done accidentally where anyone who is considered suitable to be the source of data will be sampled in this research. The analysis tool that is used is multiple linear regression. The result of the regression analysis states that green product and green promotion have significant influence on purchase intention of Eco bouquet products.
\end{abstract}

Keywords: Green Product, Green Promotion, Purchase Intention

Abstrak: Maraknya isu lingkungan menuntut unit-unit usaha mengedepankan keberlanjutan (sustainability) dalam sistem maupun produk mereka. Masyarakat lambat laun semakin sadar akan kerusakan lingkungan hidup dan upaya-upaya untuk melestarikan lingkungan. Dalam kondisi seperti ini, produk ramah lingkungan dimunculkan oleh beberapa industri produk dan jasa. Penelitian ini bertujuan untuk mengetahui apakah bagian dari konsep green marketing mix yaitu green product dan green promotion memiliki dampak positif terhadap minat beli produk Eco Bouquet. Variabel yang digunakan yaitu Green Product (X1), Green Promotion (X2) dan Minat Beli (Y). Obyek penelitian ini adalah florist yang menyediakan buket bunga dan souvenir yang ramah lingkungan. Populasi dalam penelitian ini adalah potential buyer Noir Florist, yaitu seluruh konsumen yang tahu tentang produk florist secara umum, konsumen yang pernah melakukan pembelian dan seluruh pengikut media promosi florist Eco Bouquet yang berjumlah 150 orang. Pengambilan jumlah sampel pada penelitian ini menggunakan teknik accidental sampling pada potential buyer Noir Florist, yaitu teknik yang dilakukan secara kebetulan dimana siapa saja yang dianggap cocok menjadi sumber data yang akan menjadi sampel dalam penelitian ini. Alat analisis yang digunakan adalah regresi linear berganda. Hasil analisis regresi menyatakan bahwa green product dan green promotion memiliki pengaruh yang signifikan terhadap minat beli produk Eco bouquet.

Kata Kunci: Green Product, Green Promotion, Minat Beli

\section{PENDAHULUAN}

Sampah menjadi salah satu alasan penyebab rusaknya lingkungan hidup yang sampai saat ini masih menjadi keresahan bagi dunia, terutama bagi Indonesia karena setiap harinya 
Indonesia menghasilkan 175.000 ton sampah yang setara dengan 64 juta ton sampah per tahunnya. Sampah organik menempati peringkat pertama sebagai sampah yang paling banyak dihasilkan oleh manusia, yaitu sebesar 60\%. Sampah plastik menempati peringkat kedua sebagai sampah yang banyak dihasilkan oleh manusia, yaitu sebesar 15\% pada tahun 2015 dan angka ini terus meningkat setiap tahun-nya. Sampah kertas menduduki peringkat ketiga setelah sampah plastik yaitu sebesar 10\% dari banyaknya jumlah sampah yang dihasilkan di Indonesia. Salah satu usaha yang memberikan kontribusi terhadap isu lingkungan adalah florist yang pada dasarnya banyak memakai bahan baku yang terbuat dari kertas dan plastik, contohnya yaitu kertas wrapping yang digunakan untuk membungkus rangkaian bunga.

Melihat isu lingkungan yang terjadi, maka banyak bisnis yang saat ini membuat produk ramah lingkungan yang salah satunya adalah Eco Bouquet. Eco bouquet merupakan produk rangkaian bunga yang menggunakan bahan baku yang terbuat dari kertas daur ulang dan kain goni untuk packaging dimana akan menggantikan plastik sebagai bahan baku packaging yang lama. Kirgiz (2016) menjelaskan definisi dari green product yaitu produk yang tidak mencemari bumi atau menghabiskan sumber daya alam dan dapat didaur ulang atau dipertahankan. Green product semakin diperhatikan karena adanya pergeseran pola hidup dari produk yang konvensional ke produk yang menggunakan bahan alami, bahan daur ulang, dan baik untuk lingkungan (Mahmoud, 2017). Promosi menurut Keller \& Kotler (2016) adalah kegiatan untuk mendapatkan minat beli masyarakat dengan menyampaikan pesan-pesan menarik dan meningkatkan kesadaran pembeli akan suatu produk atau jasa. Green ads merupakan kegiatan menyampaikan pesan-pesan menarik dan meningkatkan kesadaran pembeli terhadap lingkungan dalam mempromosikan produk yang ramah lingkungan (Kirgiz, 2016). Noir Florist akan menggunakan green ads sebagai wadah untuk mempromosikan produk eco bouquet melalui media sosial yaitu Instagram. Green ads ini berisi tentang konten yang meningkatkan kesadaran konsumen akan masalah lingkungan.

Florist membuat Eco bouquet dibuat dengan harapan pembeli mampu berkontribusi dalam langkah pelestarian lingkungan saat melakukan pembelian produk tersebut. Respon dari konsumen mengenai green product penting untuk diketahui apakah green marketing yang dilakukan selama ini berdampak kepada minat beli green product. Bisnis yang mengusung konsep social entrepreneur khususnya tentang hal-hal lingkungan masih belum mendapat banyak perhatian dari masyarakat karena sebagian besar masyarakat masih belum aware dengan isu lingkungan yang terjadi dan bagaimana dampaknya di masa yang akan datang apabila kita belum memulai melakukan sesuatu untuk mencegah hancurnya ekosistem. Hal ini tentu perlu mendapatkan perhatian lebih dari peneliti dalam menerapkan konsep green marketing karena selama ini masih belum banyak penelitian yang menunjukkan hasil yang akurat tentang minat beli masyarakat, khususnya terhadap produk-produk yang ramah lingkungan.

\section{TELAAH KEPUSTAKAAN}

Green marketing secara konseptual merupakan respons pemasaran terhadap dampak lingkungan yang berasal dari setiap kegiatan operasional perusahaan, mulai dari kegiatan perancangan produk, proses produksi, pengemasan produk, penggunaan produk, hingga pembuangan produk atau jasa (Setiyaningrum et al, 2016). Menurut Polonsky dalam Kirgiz (2016), konsumen biasanya menggambarkan green marketing seperti kegiatan pemasaran yang dapat didaur ulang, ramah lapisan ozon dan ramah lingkungan. Kegiatan pemasaran ini meliputi produk, proses produksi, pengemasan, harga, penyediaan, logistik dan kegiatan promosi. Green product didefinisikan sebagai produk yang tidak merusak bumi atau menghabiskan sumber daya alam dan dapat didaur ulang atau dipertahankan (Shamdasani et al, dalam Kirgiz, 2016). Menurut Mahmoud (2017), green product merupakan produk yang aman secara ekologis yang dapat memfasilitasi tujuan jangka panjang untuk melindungi dan melestarikan habitat alami. Green product juga diartikan sebagai produk yang diproduksi 
menggunakan bahan-bahan yang tidak beracun, yang dirancang untuk mengurangi konsumsi sumber daya alam yang berlebihan, mengurangi penggunaan bahan baku yang berbahaya; polusi dan limbah, melindungi lingkungan dengan cara melestarikan energi atau sumber daya yang dibutuhkan untuk meminimalisasi dampak lingkungan yang merugikan melalui seluruh siklus hidup produk. Menurut Kirgiz (2016), terdapat 4 konsep yang harus dimiliki green product, yaitu: satisfaction, sustainability, sosial acceptability, dan safety. Kusuma et al, (2017) memberikan 9 indikator green product, yaitu: 1)produk tidak mengandung racun, 2)produk lebih tahan lama, 3)produk menggunakan bahan baku yang terbuat dari bahan daur ulang, 3) produk menggunakan bahan baku yang dapat di daur ulang, 4)produk tidak menggunakan bahan yang dapat merusak lingkungan, 5)menggunakan kemasan yang sederhana, 6)tidak berbahaya bagi makhluk hidup, 7)tidak membuang banyak energi dan sumber daya lainnya selama kegiatan pemrosesan, penggunaan, dan penjualan, 8)tidak menghasilkan sampah yang tidak berguna akibat kemasan dalam jangka waktu yang singkat.

Green promotion melibatkan penyampaian informasi tentang bagaimana upaya dan komitmen perusahaan dalam pelestarian lingkungan kepada konsumen. Green promotion dalam green marketing mix mencakup berbagai kegiatan seperti paid advertising, public relations, sales promotion, direct selling, dan on-site promotion. Menurut Kirgiz (2016), terdapat beberapa kegiatan promosi yang menganut praktik green marketing adalah seperti periklanan, personal selling, sales promotion, komunikasi point of sale, direct selling dan public relations yang berdasar pada kesadaran lingkungan. Berdasarkan teori diatas, dapat disimpulkan bahwa green promotion merupakan kegiatan untuk mendapatkan minat beli masyarakat dengan menyampaikan pesan-pesan dan informasi lingkungan aktual dan meningkatkan kesadaran konsumen akan produk atau jasa yang ramah terhadap lingkungan. Menurut Kirgiz (2016), terdapat 4 tipe informasi yang perlu disajikan dalam iklan, yaitu: product orientation, production process orientation, image orientation, dan green information. Nandini (2016), memberikan 3 indikator green promotion dalam promosi dan iklan yaitu: menggambarkan hubungkan antara produk atau jasa dengan lingkungan secara langsung, mempromosikan pola hidup sehat dan hijau dengan menggunakan produk yang diciptakan, dan menampilkan citra perusahaan terhadap tanggung jawab lingkungan sekitar.

Minat beli adalah tindakan atau tingkah laku yang bersifat individu dan berhubungan langsung dengan sikap diri yang berminat terhadap produk atau jasa yang mempunyai keinginan untuk mendekat atau mendapatkan produk atau jasa tersebut Adi dan Oktarina (2016),. Minat beli seseorang juga akan muncul ketika konsumen merasa tertarik dan menunjukkan tanggapan yang positif terhadap produk atau jasa yang ditawarkan oleh produsen (Kotler dalam Mulyana, 2016). Minat beli juga merupakan petunjuk bagi konsumen dalam melakukan pembelian, perencanaan, dan melakukan kegiatan yang relevan seperti memberikan saran atau rekomendasi, memilih, dan mengambil keputusan dalam pembelian produk atau jasa (Rossister dan Percy dalam Mulyana, 2016). Menurut Abzari et al. (2014; Putri 2016), terdapat 4 dimensi dari minat beli, yaitu: minat transaksional, minat referensial, minat preferensial, dan minat eksploratif.

\section{METODOLOGI PENELITIAN}

Penelitian ini menggunakan jenis metode penelitian kuantitatif dimana pengumpulan data menggunakan angket / kuesioner sebagai sarana pengumpulan data sehingga dapat dianalisis secara statistik. Penelitian kuantitatif berguna untuk menguji hipotesis yang sudah ditentukan dan meneliti hubungan antar variabel agar lebih mudah diukur dan dianalisis, sehingga dapat lebih diketahui kebenarannya dari penelitian yang diteliti (Bungin, 2014). Populasi yang terlibat dalam penelitian ini adalah potential buyer di florist eco boquet di kawasan pasar kembang di Kota Suabaya. Kriteria potential buyer yaitu seluruh konsumen yang tahu tentang eco boquet secara umum dan konsumen yang pernah melakukan pembelian serta mengetahui media promosi dari florist eco boquet. Teknik pengambilan sampel pada 
penelitian ini menggunakan teknik accidental sampling, dimana merupakan bentuk pengambilan sampel yang dilakukan secara kebetulan, dimana siapa saja yang dianggap cocok menjadi sumber data yang akan menjadi sampel dalam penelitian ini sebanyak 150 responden yang mengisi kuesioner dari 200 kuesioner yang disebar. Teknik analisis statistik menggunakan analisis regresi berganda dengan menggunakan variabel penelitian dependen adalah minat beli transaksional (Y) dan variabel independent dalam penelitian ini adalah green product (X1) dan green promotion (X2)

\section{ANALISA \& PEMBAHASAN \\ Analisis Linear Berganda}

Teknik analisis data yang digunakan untuk menguji hipotesis dalam penelitian ini adalah analisis regresi linear berganda yang bertujuan untuk menguji pengaruh green product dan green promotion terhadap variabel minat beli transaksional. Hasil analisis dapat dilihat di tabel dibawah ini:

\begin{tabular}{l|ccc} 
& \multicolumn{3}{c}{ Tabel 1 } \\
Analisis Regresi Berganda & \\
Variabel & t & Sig. & Kesimpulan \\
\hline Green Product $(\mathrm{X} 1)$ & 5,068 & 0,000 & Signifikan \\
Green Promotion $(\mathrm{X} 2)$ & 5,129 & 0,000 & Signifikan \\
\hline Dependent Variabel: Minat Beli $(Y)$ & &
\end{tabular}

\section{Pengaruh Green Product Terhadap Minat Beli}

Hasil uji t pada variabel green product menunjukkan angka $0,000<0,05$ sehingga variabel green product berpengaruh secara signifikan terhadap minat beli, sehingga dapat disimpulkan bahwa green product memberikan pengaruh secara signifikan terhadap minat beli diterima. Hal tersebut sesuai dengan penelitian terdahulu yang dilakukan oleh Mahmoud (2017) yang menyatakan bahwa green product mempengaruhi minat beli konsumen dengan menunjukkan sikap konsumen yang peduli terhadap lingkungan, yang secara positif mempengaruhi minat beli konsumen terhadap produk ramah lingkungan. Melihat hasil pengujian hipotesis tentang green product, dapat disimpulkan bahwa masyarakat saat ini semakin menyadari pentingnya melestarikan lingkungan dan mulai menerapkan gaya hidup ramah lingkungan, khususnya di Surabaya. Berdasarkan penelitian yang telah dilakukan, potential buyer menunjukkan sikap yang peduli terhadap lingkungan yakni dengan melakukan langkah kecil untuk ikut melestarikan bumi, termasuk diantaranya yaitu membeli produk Eco bouquet yang nantinya dapat membawa perubahan besar di masa depan dengan tujuan yaitu menciptakan lingkungan yang sustainable. Jika suatu produk dinyatakan lebih ramah lingkungan dan memiliki manfaat terhadap pelestarian lingkungan, maka konsumen menunjukkan sikap lebih tertarik untuk membeli produk yang ramah lingkungan.

\section{Pengaruh Green Promotion Terhadap Minat Beli}

Hasil uji t pada variabel green promotion menunjukkan angka $0,000<0,05$ sehingga variabel green promotion berpengaruh secara signifikan terhadap minat beli, sehingga dapat disimpulkan bahwa green promotion memberikan pengaruh secara signifikan terhadap minat beli diterima. Hal tersebut sesuai dengan penelitian terdahulu yang dilakukan oleh Mahmoud (2017) yang menyatakan bahwa green promotion mempengaruhi minat beli konsumen melalui iklan yang memuat informasi tentang produk ramah lingkungan dimana secara positif berdampak pada minat beli produk ramah lingkungan. Melihat hasil pengujian hipotesis tentang green promotion, dapat disimpulkan bahwa masyarakat saat ini semakin menyadari pentingnya melestarikan lingkungan dan memulai menerapkan gaya hidup ramah lingkungan, khususnya di Surabaya. Berdasarkan penelitian yang telah dilakukan, potential buyer memberikan respon yang positif terhadap iklan dengan konsep ramah lingkungan yang dipromosikan melalui media promosi seperti Instagram, Facebook, endorsement, paid promote, dan brosur, sehingga dapat disimpulkan bahwa jika suatu perusahaan memasarkan produk yang ramah lingkungan dengan menampilkan informasi sekitar fakta mengenai 
pentingnya ikut melestarikan lingkungan dan memuat iklan ramah lingkungan yang mengandung gaya hidup yang ramah lingkungan, maka konsumen menunjukkan sikap lebih tertarik untuk membeli produk yang ramah lingkungan.

\section{KESIMPULAN DAN SARAN}

Berdasarkan hasil penelitian data dalam penelitian ini, dapat ditarik kesimpulan bahwa Green Product (X1) berpengaruh positif terhadap minat beli produk Eco bouquet, sehingga hipotesis pertama (H1) pada penelitian ini yang menyatakan bahwa variabel green product (X1) berpengaruh terhadap minat beli (Y). kesimpulan kedua yaitu Green Promotion (X2) berpengaruh positif terhadap minat beli produk Eco bouquet, sehingga hipotesis kedua (H2) pada penelitian ini yang menyatakan bahwa variabel green promotion (X2) berpengaruh terhadap minat beli (Y). Saran yang dapat diberikan dimana perusahaan florist harus lebih aware dengan lingkungan yang terjadi saat ini dimana lingkungan sudah menunjukkan isu-isu lingkungan yang masih minim untuk diatasi. Melihat isu lingkungan dan kebijakan pemerintah yang terjadi, perusahaan harus mempertimbangan produk-produk yang ditawarkan, apakah produk memiliki dampak yang negatif terhadap ekosistem. Hal tersebut dapat dilihat dari hasil penelitian yang menunjukkan bahwa green product dan green promotion berpengaruh terhadap minat beli konsumen terhadap produk yang ramah lingkungan. Peneliti selanjutnya disarankan untuk melihat variabel lain yang berpengaruh signifikan terhadap minat beli, khususnya untuk produk yang ramah lingkungan yang memungkinkan untuk diteliti karena variabel yang digunakan dalam penelitian ini masih terbatas pada green product, green promotion, dan minat beli. Masih ada variabel lainnya yang memiliki pengaruh terhadap minat beli, seperti green place, green price, environmental knowledge, dan lain-lain. Sehingga masih sangat memungkinkan untuk dilakukannya penelitian lebih lanjut kedepannya untuk mendapatkan gambaran yang lebih luas mengenai minat beli, khususnya untuk produk yang ramah lingkungan. Penelitian ini memiliki keterbatasan dimana kuesioner dari responden yang didapatkan kurang dari jumlah kuesioner yang disebarkan sehingga dirasakan dapat mengganggu hasil dari olah data.

\section{DAFTAR PUSTAKA}

Baqiroh, N.F. (2019, February 21). Timbulan Sampah Nasional Capai 64 juta ton per tahun. Dipetik October 21, 2019, dari bisnis.com: https://ekonomi.bisnis.com/read/20190221/99/891611/timbulan-sampah-nasionalcapai-64-juta-ton-per-tahun

Bungin, B. (2015). Metodologi Penelitian Sosial \& Ekonomi: Format-format Kuantitatif dan Kualitatif untuk Studi Sosiologi, Kebijakan Publik, Komunikasi, Manajemen, dan Pemasaran. Jakarta: Prenadamedia Group.

Dahlstrom, R. (2011). Green Marketing Management (International Edition). Canada: SouthWestern Cengage Learning.

Govender, J. (2016). The influence of green marketing on consumer purchase behavior. Environmental Economics, 77-85.

Indonesia, C. (2018, April 25). Riset: 24 Persen Sampah di Indonesia Masih Tak Terkelola. Dipetik October 21, 2019, dari cnnindonesia.com: https://www.cnnindonesia.com/gayahidup/20180425101643-282-293362/riset-24-persen-sampah-di-indonesia-masih-takterkelola

Kirgiz, A. (2016). Green Marketing: A case study of the Sub-Industry in Turkey. London: Palgrave Macmillan.

Kotler, P. (2016). Principles of Marketing (16 ${ }^{\text {th }}$ Global Edition). England: Pearson Education Limited.

Kotler, P. (2016). Marketing Management (15 ${ }^{\text {th }}$ Global Edition). England : Pearson Education Limited. 
Kusuma, E.S. (2017). Pengaruh strategi green marketing dan pengetahuan lingkungan terhadap keputusan pembelian melalui minat beli sebagai variabel intervening (Studi pada member Tupperware di Kota Rangkasbitung). Jurnal Riset Bisnis dan Manajemen Tirtayasa, 33-50.

Mahmoud, T. (2017). Impact of green marketing mix on purchase intention. International Journal of Advanced and Applied Sciences, 127-135.

Nandini, B. (2016). Green Marketing a way to sustainable development. Anveshana's International Journal Research in Regional Studies, Law, Social Science, Journalism and Management, 20-26.

Nasirun, N. N. (2019). Role of marketing mix and halal certificate towards purchase intention of agro based products. International Journal of Modern Trends in Business Research, $37-46$.

Osiyo, A. (2018). Pengaruh green marketing terhadap green brand image dan purchase intention pelanggan pada Starbuck Coffee Malang.

Priyatno, D. (2014). SPSS 22: Pengolah Data Terpraktis. Yogyakarta: Andi Yogyakarta.

Rahayu, L.A. (2017). Pengaruh Green marketing terhadap keputusan pembelian konsumen (Survei pada konsumen The Body Shop di Indonesia dan di Malaysia). Jurnal Administrasi Bisnis, 121-131.

Rahman, F.S. (2017). Pengaruh Green marketing mix terhadap keputusan pembelian konsumen produk Tupperware di Samarinda. Forum Ekonomi Fakultas Ekonomi dan Bisnis Universitas Mulawarman, 119-130. 